\title{
ENVIRONMENTAL CHANGES IN THE CITY OF PANČEVO
}

\author{
Vedran Živanović ${ }^{* 1}$ \\ "University of Belgrade - Faculty of Geography, Belgrade
}

\begin{abstract}
Pančevo is an old industrial center in the Banat region. The development of industry and the environment in this city are in the causa - effect relationship: industrialization follows increased degradation of the environment. This relationship was particularly disturbed in the second half of the 20th century, after the construction of a large chemical and petrochemical industrial complex, on the city periphery. The development of industry has negatively affected all elements of city environment. The saturation of air with harmful substances such as benzene, ammonia, sulfur dioxide, soot and suspended particles has become a daily occurrence. Increased concentration of harmful substances in the air directly affects the pollution of the soil - the most important natural resource of Pančevo. A chronic problem of excessive pollution of the surface waters is a consequence of insufficiently built and inefficient sewage system, as well as insufficiently purified industrial water discharged into the recipients. Also, it is necessary to conduct a complex and multidisciplinary research on the long - term consequences of the NATO bombardment, because the amount of harmful substances have melt in the water, air and soil during the two and a half months in 1999, indicate a significate negative changes in the environment of Pančevo.
\end{abstract}

Key words: Pančevo, environment, pollution, chemical industry.

${ }^{1}$ Corresponding author: V. Živanović, University of Belgrade - Faculty of Geography, Studentski trg 3/III, 11,000 Belgrade, Serbia; e-mail: vedran.zivanovic@gmail.com 


\section{Introduction}

Over a long period of time, a geographical interest in environmental issues was related to the search for effects of nature on humans, i.e. social groups and their structure (Милинчић, Souliotis, Михајловић \& Пожар, 2014). Since the mid-eighteenth century and the beginning of the First Industrial Revolution, anthropogenic factor has become an increasingly important in environmental changes at the global level. In the process of industrialization and urbanization, the cities have emerged as the leading centers of emission of the pollutants. The development of industry in the cities and urban population growth has caused a number of ecological problems that are reflected in pollution of the most important elements of the environment: water, air and soil. In accordance with the mentioned, the degrading impact of cities to the environment has become one of the major research subject in many environmental studies (Ebenstein, 2012; Esparza et al., 2012; Horváth, Szúcs \& Bidló, 2015; Cheng, 2016; Kosheleva \& Nikiforova 2016; Avenell, 2017, etc.).

Esparza et al. (2012) have research the relationship between the city and the environment through the city life quality model. Environmental condition is inversely proportional to the spatial and population expansion of the city. As a place of population growth and industrial activity, cities concentrate resources and generate waste to the point where both man and the environment are overloaded, and the management capacities are limited.

Spatial expansion into the former rural areas is one of the aspects of negative impact of the cities to the environment. By construction of Southern industrial zone in Pančevo, large areas of arable land have disappeared, and the village settlements of Vojlovica and Starčevo have been spatially connected to the city. According to Lawrence and Engelke (2005), construction of large industrial complex has a double negative impact on the groundwater. Former surface layer of the soil is covered with concrete of asphalt, which affects retention of large amount of atmospheric water on the surface. Direct consequence of these activities is reduction of level and supplies of groundwater. On the other hand, adverse impacts on groundwater quality are the result of production process, or some accidental outflow of harmful substances to the surrounding soils (Lawrence \& Engleke, 2005).

In their recent study, Zheng and Kahn (2013) indicate the air pollution and production of gas with greenhouse effects as two leading indicators of environmental pollution. Highly developed countries have taken concrete steps towards reducing environmental pollution of industrial cities. First, 
empirical research has confirmed that industrial activity directly affects air pollution in a nearby city (the effects of forge and petroleum refinery on air quality in Pittsburgh and Richmond). Next step was deindustrialization of the largest cities in United States. Deindustrialization was carried out through the modernization of existing and construction of new roads, which have provided easier access to the new and cheaper land on the distant city periphery. Lower electricity prices and a number of other reliefs accelerated the process of industry relocation (Kahn \& Mansur, 2013). There are no objective possibilities for relocation the largest polluter of environment in Pančevo (South industrial zone), but by introducing modern technology, emission of harmful gases can be greatly reduced. The quality modernization of production facilities, with emphasis on reduced emissions of toxic substances, is an effective way to improve conditions in the city environment.

With air and water, soil is among the most polluted elements of the environment in the industrial cities. Soil saturation with heavy metals is one of the most serious forms of pollution. Once they reach the soil, heavy metals are retained by hundreds (even thousands) years and to large extent are adversely affecting the agricultural production. There are two main sources of heavy metals in the soil: natural - consequence of the geological structure; and anthropogenic - due to soil saturation by agrochemicals or industrial waste (Xiaoyu et al., 2013). Generally, urban soils are considered as permanent recipients of harmful elements, materials and other pollutants. The source of dangerous elements in urban areas may be different: industrial activity, coal combustion, automotive exhaust, inadequate disposal of waste, etc. (Karim, Qureshi, Mumtaz \& Qureshi, 2014). The soil in the territory of Pančevo faces all of the mentioned problems, which is why maintaining its quality is one of the major challenges for preserving environment in the coming years.

The favorable geographical position of Pančevo, determined by the proximity of Belgrade and the Danube, as well as major roads (Belgrade Timisoara road and longitudinal road through Banat region: Pančevo - Zrenjanin - Kikinda, proximity to highways E-70 and E-75) conditioned the early development of industry in this area. As early as the 18th century, Pančevo has developed into one of the most important industrial centers in Banat region. During the second half of the 20th century, in the process of the industrialization, several dozen large industrial plants were opened in the city. Some of them were considered as the giants in the territory of former Yugoslavia. The intensive development of the industry has greatly influenced changes in the environment. Exhaust gases and wastewater simultaneously pollute the air, water and soil. The environment of Pančevo was especially threatened dur- 
ing the NATO bombing in 1999, when large amounts of toxic and dangerous chemicals were released into the air, poured out into the surrounding soils and were discharged into the main rivers (Danube and Tamiš).

Aim of this paper is to determine main sources of pollution of the most important elements of environment: water, air and soil, as well as proposing measures that will contribute reducing emissions of harmful substances. Decades of air pollution have extremely negative consequences for the health of the local population. The paper analyzes air pollution by the most dangerous pollutants. It has also been pointed to a change in the structure of the main pollutants. By modernization of production process in the refinery, emission of benzene has significantly reduced, so that soot and suspended particles (especially during the winter months) make the biggest polluters of urban air. One of the aims of this paper is to point out the need for a complete, systematic, fundamental and multidisciplinary research of long-term consequences of NATO bombing on the environment.

\section{Sources of environmental pollution}

Largest sources of environmental in Pančevo are the chemical and petrochemical industries. This complex is located in the Southern industrial zone of the city and it is consisted of: "HIP Azotara" (mineral fertilizer plant), "HIP Petrohemija" (petrochemical product plant) and Oil Refinery. In addition to direct emission of harmful substances into the environment, one of the main causes of increased environment pollution in Pančevo is position of the South industrial zone in relation to the city. Petrochemical industrial complex was built on the direction of the most dominant winds in the region (from the northwest and southeast direction). Northwest winds carry contaminants to nearby rural settlements (Starčevo and Omoljica) and arable soils in their surroundings. During the wind blowing from the southeast direction there is a noticeably higher concentration of pollutants in the air, in the city of Pančevo. Another important factor in the process of environmental pollution is obselte industrial technology, which has not been renewed for several decades, nor is it invested enough to improve production proces and reduce emission of harmful substances. The most extensive steps in technological improvement were made in the Oil Refinery, after 2009, and investments by Russian "Gazprom". Environmental pollution in Pančevo (especially during the winter months) is also influenced by exhaust automobile gas, as well as the increased concentration of soot in the air from a large number of individual and collective furnaces. 


\section{Air pollution}

Changes in the environment in Pančevo are monitored by measuring the concentration of harmful substances in water, air and soil. Over the past few years, number of stations with a 24-hours systematic measurement of air quality has been increased. A larger number of locations for monitoring the concentration of harmful substances contribute to a better quality of pollution monitoring. Air pollutants in Pančevo can be divided into basic (sulfur dioxide, nitrogen dioxide, soot, total suspended particles) and specific (ammonia, benzene, toluene, xylene, six heavy and six toxic metals) (Zavod za javno zdravlje Pančevo, 2011). According to data of the Public health institute of Pančevo and Environmental protection agency, since 2001, the biggest polluters of air in the city and its surroundings are ammonia, benzene, soot and suspended particles. Over the last 16 years, the modernization of production plants, higher and stricter quality of control, mean annual concentration of benzene and ammonia are significantly reduces (Graph 1 and 2). However, despite the taken measures, concentration of ammonia continues to exceed maximum allowable amounts, while air pollution with benzene is present very rarely and exclusively at the daily level (Zavod za javno zdravlje Pančevo, 2011).

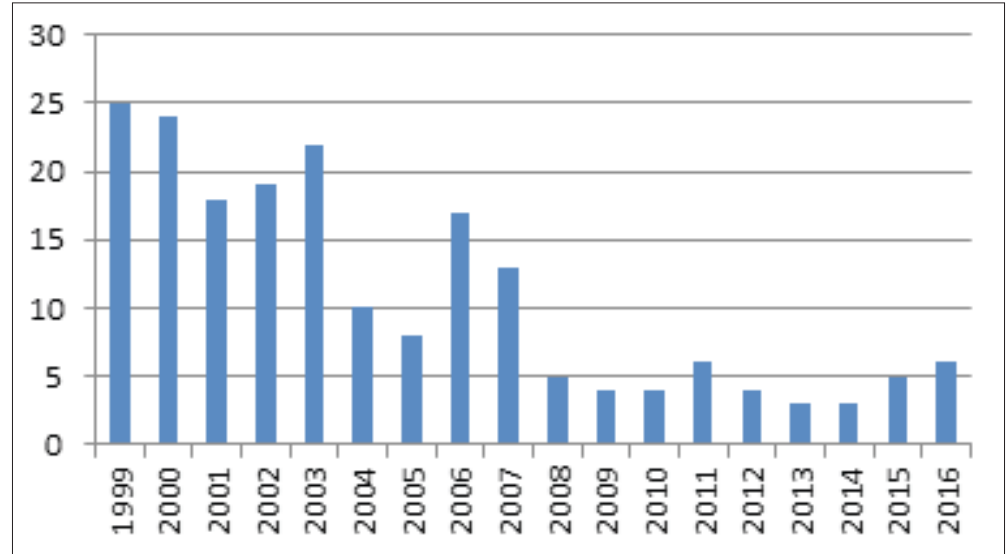

Graph 1 - Mean annual concentration of benzene in the city of Pančevo in $\mathrm{mg} / \mathrm{m}^{3}$ from 1999 to 2016.

Source: Zavod za javno zdravlje Pančevo, 2011; Секретаријат за заштиту животне средине, 2006. - 2016.; Завод за јавно здравље Панчево, 2017. 


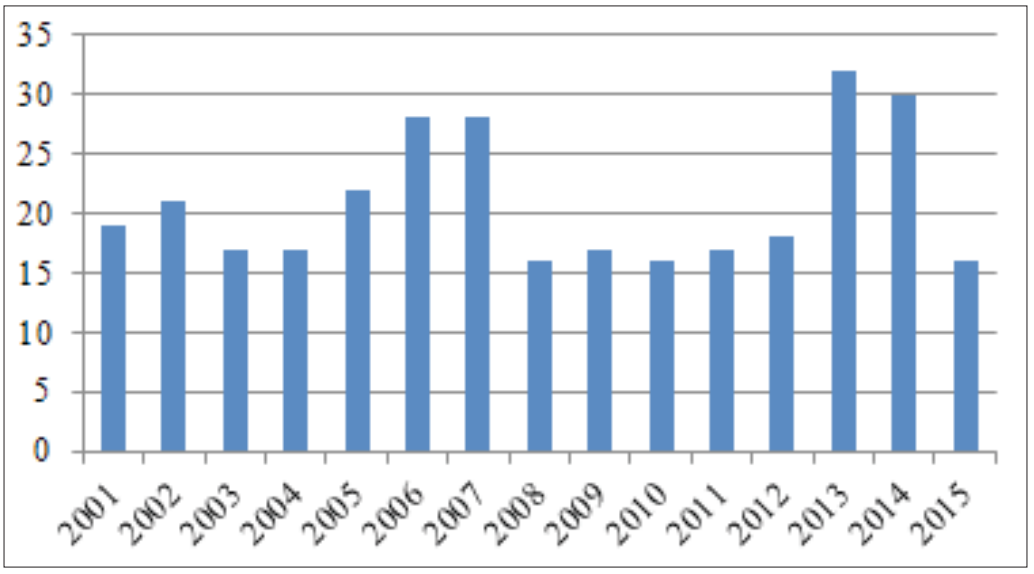

Graph 2 - Mean annual concentration of ammonia in the city of Pančevo in $\mathrm{mg} / \mathrm{m}^{3}$ from 2000 to 2015

Source: Zavod za javno zdravlje Pančevo, 2011; Секретаријат за заштиту животне средине, 2006. - 2016.; Завод за јавно здравље Панчево, 2017.

According to measurements of the system for automatic air quality monitoring, a significant decrease of mean annual concentration of benzene is observed in Pančevo between 1999 and 2016. The maximum allowed mean annual concentration of benzene in one $\mathrm{m} 3$ of air is $5 \mathrm{mg}$ (Секретаријат за заштиту животне средине2, 2011). By 2008, air in Pančevo had an extremely high mean annual concentration of benzene, which in some days exceeded upper saturation limit for several tens of times. By modernizing the plant in the Southern industrial zone, but also because of more regular and quality control of emissions of pollutants, the amount of benzene in the air has been significantly reduced over the last 8 years. Average annual concentration of this substance exceeded the maximum permissible concentration in 2011 and 2016. Daily oscillations of benzene emission are distinctive. For example, the highest daily concentration of benzene in one $\mathrm{m} 3$ of air was 88 mg (Секретаријат, 2007), while in 2009 the total number of days with the exceeded upper limit of concentration was 77 (Покрајински секретаријат за урбанизам, градитељство и заштиту животне средине, 2011). The reduced concentration of benzene in air since 2009 coincides with the start of Russian Gazprom's investments in the refinery production process. This fact confirms the experts assumption that foreign companies provide better

${ }^{2}$ Hereinafter: „Секретаријат“ 
environmental protection from government - owned companies. The main reason is using of cleaner and more advanced technology and higher energy efficiency in the production process (Wang \& Jin, 2007).

In the last 15 years, the mean annual concentration of ammonia in Pančevo has significantly varied (Graph 2). The mean values range between $15 \mathrm{mg} / \mathrm{m}^{3}$ and $20 \mathrm{mg} / \mathrm{m}^{3}$ per year, with the exceptionally high annual concentration of ammonia in 2006, 2007, 2013 and 2014. Maximum allowed ammonia concentration in one $\mathrm{m}^{3}$ of air is $8 \mathrm{mg}$, which means that the air in Pančevo is overloaded with this compound (Секретаријат, 2016). High content of ammonia in the air causes a large number of health problems for local citizens. The mineral fertilizer "Azotara" is the largest ammonia emitter in the environment. Concentrations of ammonia on a daily basis are extremely oscillatory. Maximum daily concentrations of ammonia exceed the permitted limit for several times. So it was measured on the 03.08.2014. even $224 \mathrm{mg}$ ammonia per $\mathrm{m} 3$ of air (Секретаријат, 2015).

In the last few years, structure of the elements of main air pollution has changed. By reducing the emissions of benzene and ammonia, the main air pollutants have become soot and suspended particles. According to the Annual report on the state of air quality in Serbia for 2015, agglomeration of Pančevo is classified in category III (which means excessively polluted air), and suspended particles (cadmium, lead, nickel, mercury, arsenic) are separated as dominant air pollutants.

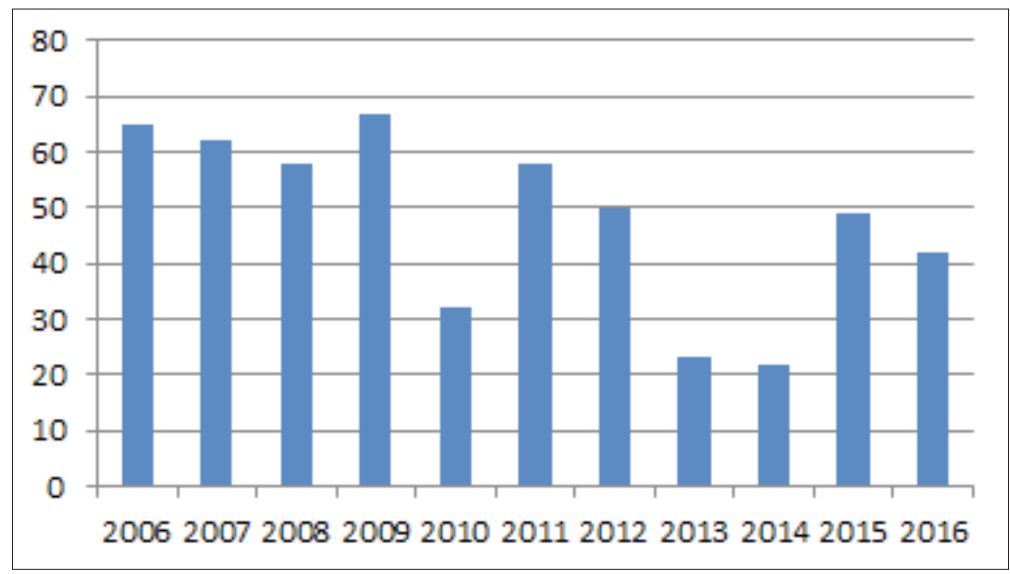

Graph 3. - Number of days with soot concentration above the limit value Source: Zavod za javno zdravlje Pančevo, 2011.; Секретаријат, 2011 - 2015.; Завод за јавно здравље Панчево, 2017. 


\section{Water pollution}

The quality of surface waters in Pančevo is influenced by release of harmful substances from industrial plants, agricultural production, municipal wastewaters that are discharged into rivers without purification, as well as high waters and dry periods. The problem of surface water pollution especially occurs during low water level. If low water occurs during the increased operation of industrial plants, it causes excessive pollution of watercourses. Oxygen deficiency usually occurs at that time, as well as the degradation of organic matter in anaerobic environmental conditions, whereby toxic substances and gases are released (Покрајински секретаријат за урбанизам, градитељство и заштиту животне средине, 2011).

Increased pollution of surface waters is also a result of natural disasters. During the flood, the concentration of iron and suspended particles increases. This affects deterioration of water quality. Such a situation was in 2006 on the Danube and Tamiš rivers. In addition to natural river flows, Nadel hydro system is also exposed to excessive pollution. It is a part of Danube-Tisa-Danube hydropower system and it represents multipurpose system envisaged for drainage, irrigation, waste supply, acceptance of excess water from the settlements, as well as used water from the industry. A large number of pollutants are concentrated at a length of $30 \mathrm{~km}$, which discharge their wastewater directly into the hydro system, without prior purification. Two biggest polluters are starch industry "Jabuka" and Pančevo dairy. Due to the low content of oxygen, excessive content of metals, and organic pollution, the waters of Nadel channel are classified into the 4th class of quality (Belić, Savić, Belić, 2003).

In the period from 2012 to 2016, water quality in Tamiš river was variable. In some years water quality corresponded to the second class. In the years of 2012, 2014 and 2015, due to reduced oxygen saturation, the content of suspended matter, as well as presence of ammonia and iron, the water quality ranged between III and IV class. Quality of Danube water is measured at the Forkontumac island. In the five-years observed period water has never satisfied criteria of the II clas of quality. Nature park Ponjavica (located in the village of Banatski Brestovac) is one of the most polluted surface water area in Pančevo. Water of Ponjavica is classified as V class (poor ecological potential) and can't be used for any purpose (Секретаријат, 2012, 2013, 2014, 2015, 2016).

Waste waters in the city of Pančevo are a significant polluter of the environment. All waste waters of industrial zone are discharged into a dedicated channel that is directly connected with the Danube river. Waste waters of Azotara are discharged directly into this chanel, while the waste waters of 
Refinery and Petrochemical industry are treated on a primary and secondary purification devices. Plant for the secondary treatment of waste waters is common to the both factories (Општина Панчево, COWI, 2004). The biggest problems related to the waste waters are: insufficiently built sewage system, lack off facilities for purification of municipal waste waters before discharging into the Danube, a large number of septic tanks, discharge of waste waters directly into the sewage system of natural watercourses by industrial entities etc. (Секретаријат, 2009).

\section{Soils pollution}

For a long time, area of the city of Pančevo has been exposed to a numerous anthropogenic influences, which have negative impacts on the quality of agricultural land. On the city periphery, in the Southern industrial zone, there are a permanent emission of acid oxides, heavy metals and other harmful substances. Since 2009, two projects for land quality research have been carried out. The project: "Fertility and contents of hazardous and harmful substances of agricultural soils in the city of Pančevo" was implemented in the three-years period (from 2009 to 2012). A new one: "Monitoring of the soil's condition and influence on plants in the city of Pančevo" represent continuation of monitoring of soil pollution (Sekretarijat za privredu i ekonomski razvoj-Odeljenje za lokalni ekonomski razvoj, 2014).

Above mentioned projects indicate over-saturation of surface layer of the soil (up to $30 \mathrm{~cm}$ depth) by some heavy metals $(\mathrm{Cd}, \mathrm{Cu}, \mathrm{Pb}, \mathrm{ZN}, \mathrm{Cr}$, As and Ni) in the vicinity of 28 industrial plants. In the wider area of Pančevo, in the cadastral municipalities that are distan from the sources of pollution, the content of heavy metals in the soils are significantly lower than the maximum allowed concentration. Analysis of pesticide content (carbamates, organophosphorus, pesticides, pyrothoids, etc.) indicates that content of these compounds in the soils are significantly below defined limit values. On these soils, production of health - safe food can be carried out. In agricultural crops, fruits and vegetables, concentration of heavy metals is also below the maximum allowed values. Althout, the results of these studies appear to be encouraging, in the soils have been recorded the presence of numerous highly dangerous organic pollutants, such as polycyclic aromatic hydrocarbons and polychlorinated biphenyls (Sekretarijat za privredu i ekonomski razvojOdeljenje za lokalni ekonomski razvoj, 2014). Heavy metals are a major problem for the environment. Once they are brought into the soil, because of their stability, they remain in it for years and even thousands of years, and hence the polluted soils require a special way of use (Покрајински секретаријат за урбанизам, градитељство и заштиту животне средине, 2011). 


\section{The consequences of NATO bombing}

During the NATO bombing of Yugoslavia in 1999, several industrial objects in the city of Pančevo were attacked. The complexes of chemical and petrochemical industries in Southern industrial zone were the target of attacks in April and May, and the consequences of destruction of these plants to the environment and population are long-term and extremely harmful. Current consequences of the bombing were multiple: combustion of large quantities of toxic chemical compounds, leakage of oil, petroleum products, ammonia, nitrogen and sulfur compounds directly into the Danube, leakage of large amount of harmful substances on surroundings soil, permanent pollution of groundwater etc. Long - term consequences are much more dangerous and harmful, and they are reflected in permanent changes in the environment that affect the health of local population.

Table 1 - Types and quantities of destroyed products in the South industrial zone

\begin{tabular}{|l|c|}
\hline Type of products & $\mathbf{t}$ \\
\hline Crude oil & 37,700 \\
\hline Benzene & 80 \\
\hline Special gasolines & 360 \\
\hline Real benzene & 1,500 \\
\hline Motor gasolines & 43,50 \\
\hline Kerosene & 12,40 \\
\hline Diesel fuel & 350 \\
\hline HVGO & 7,550 \\
\hline Ammonia and ammonia's water & 230 \\
\hline Heavy oil & 328 \\
\hline NPK fertilizer & 700 \\
\hline $\begin{array}{l}\text { Ammonium sulphate and } \\
\text { superphosphates }\end{array}$ & 45 \\
\hline Rubber & 10 \\
\hline
\end{tabular}

Source: Bogojević et al., 2002.

Total quantity of destroyed products of the Southern industrial zone in Pančevo is around 55,000 $\mathrm{t}$ (Table 1). Most of these products were destroyed by burning, due to explosion, which greatly degraded the environ- 
ment. The spatial coverage of pollution cloud was so large that the increased concentrations of harmful substances in the air were registered in neighboring countries (Bogojević et al. 2002).

During the bombing of refinery on several occasions, to the surrounding soil, in the drainage channel and directly into the Danube has been spilled around: 5,000 tons of crude oil and petroleum products, 23,000 t of ethyl carbodimide (EDC), $600 \mathrm{t}$ of hydrogen chloride (HCL), 3,000 $\mathrm{t}$ of sodium hydroxide $(\mathrm{NaOH})$, and $230 \mathrm{t}$ of ammonia. Contamination of the environment was also a consequence of incomplete combustion of large amount of nitrogen, sulfur and carbon oxides, soot particles, hydrocarbons, various carcinogenic aromatic compounds and other dangerous materials (Bogojević et al. 2002).

Economic consequences of bombing the Southern industrial zone have been calculated and they are known since the early years of the 21st century. On the other hand, negative environmental impacts have been studied only from the aspect of recording increased concentrations of pollutants and toxic substances in wider surroundings. Due to structure and quantity of harmful chemical elements and materials that have come into the water, air and soil, long-term negative consequences of environmental contamination are undoubtedly high. They are primarily reflected in continuously increased presence of harmful elements in the environment, which affects the occurrence of changes with negative consequences to the population, flora and fauna in local community. In addition to arable land in the vicinity of Pančevo, ground waters nearby chemical industrial complex are also contaminated from the effects of bombardment (this type of pollution is confirmed by continuous testing of groundwater quality sampled from pre-installed piezometers, by Public health institute of Pančevo).

Scientific researches on the impact of bombing on the environment in Pančevo are mostly of individual character. After almost two decades of NATO aggression, a complex, multidisciplinary and comprehensive analysis of long-term consequences and changes in the environment is still missing. The structure and quantity of toxic substances that have reached all elements of the environment clearly indicate the need for scientific research of the mentioned problem. A complex and multidisciplinary approach to this problem, in the form of comprehensive study of a long-term effect of contamination of environment with a large quantity of toxic substances, is of immeasurable importance for both local and wider social community. 


\section{Conclusion}

According to the classification of environmental conditions in the Spatial Plan of the Republic of Serbia, Pančevo has been classified at the most vulnerable category - the area of polluted and degraded environment, in which it is necessary to rehabilitate and revitalize degraded and endangered ecosystems and remediate the consequences of pollution. Also, the same document classified Pančevo in the areas of endangered environment with occasional exceeding of limit values of pollutants. The presence of chemical and petrochemical industries, as well as oil refinery, ranks Pančevo in the most vulnerable areas in the Republic of Serbia (hot spots) (Просторни план Републике Србије, 2010).

In order to reduce environmental pollution in the future, it is necessary further modernization of production processes of leading industries. This is particularly true for "HIP Azotara" plants, because the concentration of ammonia continuous to be above the permitted values at the daily, monthly and annual levels. Due to a lack of real technical possibilities for reducing the number of individual furnaces and their gasification, high concentration of soot and suspended particles during the winter, will remain one of the leading problems in the environmental protection policies. Excessive pollution of surface water represents a chronical problem of Pančevo. One of the solutions is reconstruction of municipal sewage network and the prevention of direct discharge of waste waters into the Tamiš and Danube. It is necessary to resume with continuous systematic monitoring of soil quality, because the soil is the most important natural resource of Pančevo. Preserving soil quality and sustainable use of its fertility should be one of the priorities in future environmental policies.

\section{Acknowledgements}

The paper is the result of the research within the project no. 176008 funded by the Ministry of Education and Science of the Republic of Serbia.

\section{References}

Avenell, S. (2017). Transnational Japan in the Global Environmental Movement. University of Hawai press.

Belić, S., Savić, R., Belić, A. (2003). Uticaj aktivnosti u slivu na promenu kvaliteta voda Nadele. Letopis naučnih radova, 1, 169-176. 
Bogojević S., Mirkov LJ., Stoimirović N., Pajević V., Krasulja S., Spasojević N. (2002). Environmental degradation as the result of NATO air-rids against Pančevo chemical plants - oil refinery / petrochemical plants / azotara fertilizer plant. Belgrade. In Antić, D., Vujić, J. (eds) Environmental recovery of Yugoslavia (pp. 23-52). Beograd: Vinča Institute of Nuclear Sciences.

Cheng, Z. (2016). The spatial correlation and interaction between manufacturing agglomeration and environmental pollution. Ecological Indicators, 61, 1024-1032. http:// dx.doi.org/10.1016/j.ecolind.2015.10.060

Ebenstein, A. (2012). The Consequences of Industrialization: Evidence from Water Pollution and Digestive Cancers in China. Review of Economics and Statistics, 94 (1), 186-201. doi: 10.1162/REST_a_00150

Esparza, J., Dicroce, L., Martini, I., Carlos, A. (2012). Detailed analysis of urban-environmental aspects in an urban life qualitymodel. Theoretical and Empirical Researches in Urban Management, 7(2), 5-21.

Horváth, A., Szúcs, P., \& Bidló, A. (2015). Soil condition and pollution in urban soils: evaluation of the soil quality in a Hungarian town. Journal of Soils and Sediments, 15(8), 1825-1835. doi: 10.1007/s11368-014-0991-4

Kahn, M,. \& Mansur, E. (2013). “Do Local Energy Prices and Regulation Affect the Geographic Concentration of Employment?", Journal of Public Economics, 101, 105-114. http:/ / dx.doi.org/10.1016/j.jpubeco.2013.03.002

Karim, Z., Qureshi, B.A., Mumtaz, M., Qureshi, S., (2014) . Heavy metal content in urban soils as an indicator of anthropogenic and natural influences on landscape of Karachi - a multivariate spatio-temporal analysis. Ecological Indicators. 42, 20-31. https:// doi.org/10.1016/j.ecolind.2013.07.020

Kosheleva, N., \& Nikiforova, E. (2016). Long - Term Dynamics of Urban Soil Pollution With Heavy Metals in Moscow. Applied and Environmental Soil Science. Volume 2016, Article ID 5602795, 10 pages. doi: http:/ / dx.doi.org/10.1155/2016/5602795

Lawrence, F., \& Engelke, P. (2005). Multiple Impacts of the Built Environment on Public Health: Walkable Places and the Exposure to Air Pollution. International Regional Science Review, 28(2), 193 - 216. doi: 10.1177/0160017604273853

Sekretarijat za privredu i ekonomski razvoj - Odeljenje za lokalni ekonomski razvoj (2014). Strategija razvoja Grada Pančeva 2014-2020., Pančevo.

Wang, H., Jin, Y. (2007). Industrial Ownership and Environmental Performance: Evidence from China. Environmental and Resource Economics, 36(3), 255-273. doi:10.1007/s10640-006-9027-x 
Xiaoyu, L. et al. (2013). Heavy metal contamination of urban soil in an old industrial city (Shenyang) in Northeast China. Geoderma, 192, 50-58. http:/ / dx.doi.org/10.1016/j.geoderma.2012.08.011

Zavod za javno zdravlje Pančevo (2011). Izvod iz izveštaja o kvalitetu vazduha u Pančevu za 2010. godinu i uporedni prikaz pojedinih parametara za period 2000-2010., Pančevo.

Zheng, S., \& Kahn, E. (2013). Understanding China's Urban Pollution Dynamics. Journal of Economic Literature, 51 (3), 731-772.

http://dx.doi.Org/10.1257/jel.51.3.731

Завод за јавно здравље Панчево (2017). Извештај о квалитету ваздуха у Панчеву за 2016. годину, Панчево.

Милинчић, M., Souliotis, L., Михајловић, Љ \& Пожар, Т. (2014). Географија и наука о животној средини. Зборник радова - Географски факултет Универзитета у Београду. 62, 1-14.

Општина Панчево, COWI (2004). ЛЕАП - Локални еколошки акциони план Панчево, Сумарни извештај, књ. 1, Панчево.

Покрајински секретаријат за урбанизам, градитељство и заштиту животне средине (2011). Животна средиа у Аутономној Покрајини Војводини; стање-изазови-перспективе, Нови Сад.

Просторни план Републике Србије до 2020. године (2010). Службени гласник Републике Србије бр. 88/10, Београд.

Секретаријат за заштиту животне средине (2016). Извештај о стању животне средине на територији Града Панчева (за 2006., 2007., 2008., 2009., 2010., 2011., 2012., 2013., 2014., 2015. и 2016. годину), Панчево. 